\title{
Start-Up to Stardom: An Access of the Growth of E-Ticketing Firm 'Book My Show'
}

\author{
Rajalakshmi Vel, P.C. Lakshmi Narayanan
}

\begin{abstract}
With the rise of E-Cinemas, Indians are watching movies like never before. As per data released by Statista, a media research agency, it is believed that nearly 20,000 movies hit the theatres every year, making India the largest movie producer worldwide. Movies are a way of social bonding for families given the multiplex culture in Urban areas. With the proliferation of technology and the reach of $4 G$, there is also the convenience of buying tickets online. Gone are the days of long queues and nonavailability of information regarding show timings. The emergence of online ticketing platforms have simplified the hassles of buying tickets through counters and increased audience showing up in theatres. The present study makes an attempt to study the rise of 'Book My Show', an online ticketing company who pioneered the model of selling movie tickets online during the early 2000s when Indian laws were not so favourable. Being an innovative start up, the company is a game-changer who transformed the movie experience of cinema goers in India. It has touched the prestigious \$ 1 billion valuation recently. The paper investigates the rise of the company to its present state by a thorough study of all the aspects of business. Through an indepth secondary data reference the study analyses the factors that contributed to the rise of the company. The study is important as it explains techno-preneurship as a medium of disrupting traditional markets.
\end{abstract}

The current study is organised as follows: Part I explores the business model of the company, how it negotiated its presence in the market and some nuances related to strategy which propelled its growth. Part II explores the dimensions of digital media that helped the company to scale up exponentially.

Key Words: E-Ticketing, E-Cinema, Techno-preneurship, Digital Media.

\section{INTRODUCTION}

With the rise of E-Cinemas, Indians are watching movies like never before. As per data released by Statista, a media research agency, it is believed that nearly 20,000 movies hit the theatres every year, making India the largest movie producer worldwide. Movies are a way of social bonding for families given the multiplex culture in Urban areas. With the proliferation of technology and the reach of $4 \mathrm{G}$, there is also the convenience of buying tickets online. Gone are the days of long queues and non-availability of information regarding show timings. The emergence of online ticketing platforms have simplified the hassles of buying tickets through counters and increased audience showing up in theatres.

The present study makes an attempt to study the rise of 'Book My Show', an online ticketing company who pioneered the model of selling movie tickets online during

Revised Manuscript Received on September 10, 2019.

Dr.Rajalakshmi Vel, Assistant Professor Vel Tech Rangarajan Dr.Sagunthala R \& D Institute of Science \& Technology , Chennai, Tamilnadu, India.

(email: drrajalakshmi@veltech.edu.in)

Dr. P.C. Lakshmi Narayanan, Dean - Academics, LIBA, Loyola College Campus, Chennai, Tamilnadu, India

(email: lakshmi.narayanan@liba.edu) the early 2000s when internet penetration was low and laws were not favourable. Being an innovative start up, the company is a game-changer who transformed the movie experience of cinema goers in India. It has touched the prestigious $\$ 1$ billion valuations recently.

\section{SIGNIFICANCE OF THE STUDY}

Given this context, the paper investigates the rise of a Start-Up to its present state of Stardom by a thorough study of all the aspects of business. The study is important as it explains techno-preneurship as a medium of disrupting traditional markets. In a country of avid movie-goers where entertainment industry is growing at a CAGR of $13 \%$ to touch Rs.2660 billion by 2023 according to EY-FICCI reports, BookMyShow.com made a huge difference by pioneering the concept of online ticketing to India. Barring the first-mover advantage, the company has managed to retain its Star Status for two decades and has survived the dotcom burst of 2000 and financial crisis of 2008 .

\section{LITERATURE REVIEW}

A literature review on the subject was done to identify the type of research studies conducted on start-ups in India. A descriptive study of the inside view of start-ups carried out by Upadhyay and Rawal in Indian context examines the landscape of start-ups, the driving forces behind starting-up and barriers to start-up. There are also good number of case studies developed on start-ups who are game changers in the industry. To mention a few are the recent studies on Big basket, Lenskart and OYO rooms. In 2016, industry body ASSOCHAM released a report on the overview of Start-ups in India. The report outlines the trend of start-ups, the conditions favouring the starting-up.

There are also other studies that focussed on the financial aspects of start-ups like the one by Uruba and Singh in 2016 titled "A study of Financial Sources for Start-up companies in India." A study by Wagh and Madhura has covered the government initiatives for entrepreneurship development especially the 'Start-Up India Stand-Up India' announced by Modi Government. While the above research studies have focused on various aspects of start-ups, the case studies are about innovative start-ups. There is no study which demonstrates techno-entrepreneurship as a medium of disrupting traditional markets. The current study is relevant as it outlines the rise of a start-up to its current unicorn status by analysing all events, decisions and strategies in the life of the company that contributed to this status.

Published By:

Blue Eyes Intelligence Engineering

\& Sciences Publication 


\section{OBJECTIVE OF THE STUDY:}

- To elucidate how online entrepreneurship has disrupted traditional market segments with a case of 'Book My Show'

\section{RESEARCH QUESTIONS:}

The study addresses the following research questions:

1. What circumstances triggered the business?

2. What was the strategy adopted to negotiate their presence in the market?

3. Given the first mover advantage, what makes them the market leader even after two decades of presence?

4. How have the business cycles impacted the business?

5. How has innovation shaped the business?

\section{METHODOLOGY OF THE STUDY}

Investigating the growth of a company requires thorough understanding of various aspects of business. Through an indepth secondary data reference, the study analyses the factors that contributed to the star status of the company. The secondary references include news published (interviews of founding team) in media, write-ups of the company in portals and the company's website. Being a closely held firm, the researchers couldn't have access to the financial statements of the company. However, newspaper reports of financials have been collected to cover the financial aspects.

The study is organised as follows: Part I explores the business model of the company, how it negotiated its presence in the market and some nuances related to strategy which propelled its growth. Part II explores the dimensions of digital media that helped the company to scale up exponentially.

\section{GENESIS OF BOOK MY SHOW}

The popular 'Houseful' board of movie halls have become a thing of past. Thanks to Book My Show, the company disrupted the conventional way of buying movie tickets through counters when it started its operations in 1999. The company enjoyed a monopoly in the segment for more than a decade until 2016. The idea behind starting up Book My Show was to make buying movie tickets easy for Indian movie goers. From over-crowded counters to lack of information about show timings, it was a doleful experience to watch movies. With the help of technology, the company addressed the gap by selling movie tickets online at a time when the legal framework for such online selling of movie tickets was not in place.

Today the company accounts for two-thirds of all tickets sold online1 with around 1.5 crore tickets sold per month. Known by the name of Bigtree Entertainment Pvt Ltd, the company has offices in five countries and serves more than 30 million customers worldwide. It also plans to make foot prints in 15-20 countries frequented by Indians. Like Newton reawakening, the idea of starting an online ticketing venture dawned upon the founder, Ashish Hemrajani sitting under a tree listening to radio announcements selling rugby tickets. The potential of the idea was strong enough for the founder to pursue his dream of launching Book My Show.
During the early days the founders named the company as 'Go for Ticketing' which was later re-branded as 'India Ticketing'. Finally, the name 'Book My Show' was suggested by an intern in a contest held by the company which went on to become a brand.

\section{RANGE OF SERVICES}

Movie ticketing is the core business segment of the company and they account for nearly $60 \%$ of the business. However, the company diversified into non-movie segment such as dramas/theatre, sports events and music events. By further launching booking for monuments, international events the company built a niche category for itself. The company has also announced activities booking wherein one can look for activities happening in any place and buy tickets for the same. Customers can choose the web or app version to avail of the services. Apart from ticketing services the company gives valuable information to customers in the form of reviews and trailers with enthusiastic responses from customers.

\section{INDIAN MEDIA AND ENTERTAINMENT INDUSTRY:}

The Indian Media \& Entertainment Industry which is on the cusp of a digital revolution is expected to grow at a CAGR of $13 \%$ over 2018-23 according to EY-FICCI reports. The sector is projected to reach Rs.2.35 trillion by 2021. Film segment occupies the third place in the industry with a market size of Rs.159 billion after television (Rs.651.90 billion) and print segment (Rs.318.90 billion) As of 2017, the industry provides employment to 5 million people both direct and indirect employment according to industry report of Indian Brand Equity Foundation. The FDI limits in the sector has been relaxed to $100 \%$.

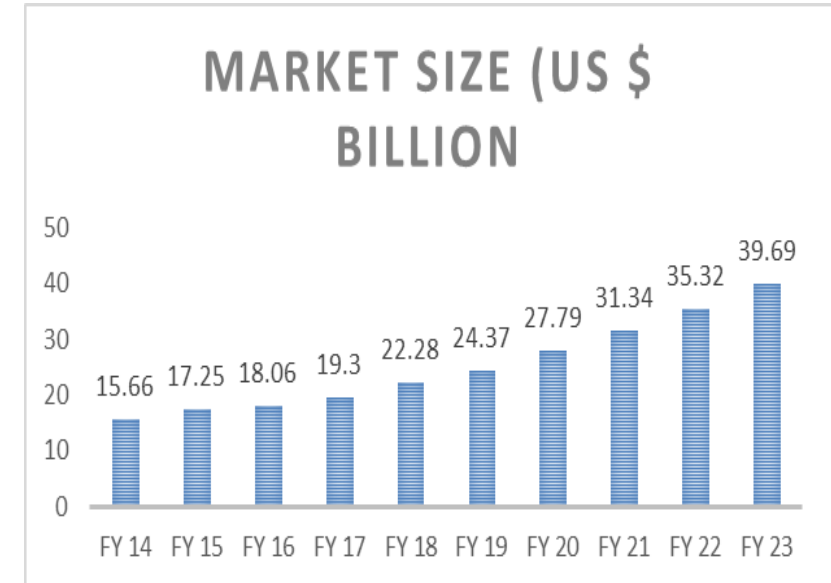

Source: www.ibef.org

\section{BUSINESS MODEL AND WORK FLOW CHAIN OF BOOK MY SHOW}

As a third party vendor for movie tickets the company has employed the technology for effective distribution of movie tickets and show timings thereby giving real-time availability of movie tickets to customers. Software 
solutions using APIs have aided in the integration of vendors with theatres and multiplexes thereby creating a seamless process of ticket sales as well as food sales. The same technology is replicated for other events and show bookings. The ticketing revenue which accounts for $70 \%$ comes from internet handling fees, commission on booking for movie \& events and convenience fees. Non-ticketing revenue stream consists of advertising and promotions carried out for any company on the pages of Book My Show and this account for $30 \%$ of total revenue.

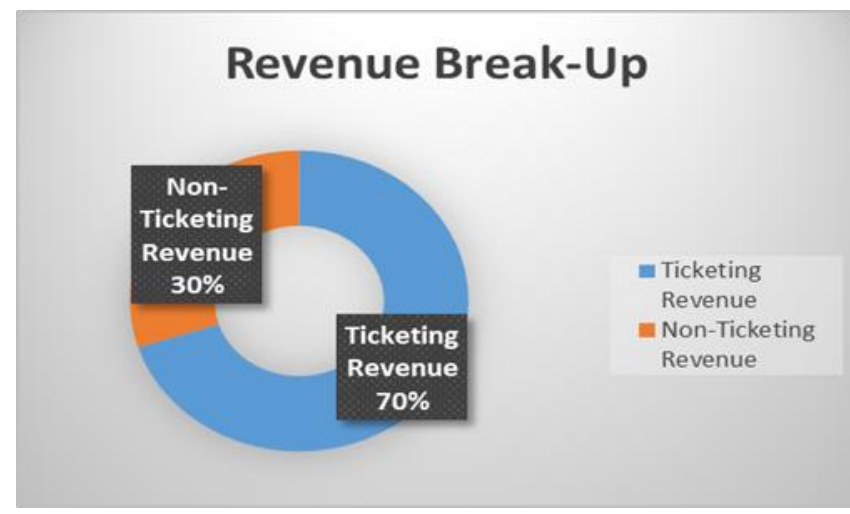

\section{KEY FACTORS FOR SUCCESS \& RESULTS}

The launch of online booking for movie-tickets during 1999 was totally a new business concept. The innovative idea disrupted the traditional form of booking. The company gets the credit for building an ecosystem of online ticket purchase, as a result of which it enjoys a competitive advantage. It has evolved from being a movie-ticketing company to a go-to destination for all events and concert bookings. The company is on the cusp of a major development as it has moved from movie ticketing to live events and shows. It's a very awaited space for a two-decade old successful company who wants the revenue proportion to change favourable in terms of non-ticketing. In its strategy to grow its non-movie ticketing the company has hosted Ed Sheeran concert and Disney musical Aladdin in India. It has tied up with international players and hosted the debut show of Cirque De Soleil's Bazzar in India. At a national level the company became an official partner for IPL tickets. Its also the only partner for Indian Grand Prix, Formula 1. This is a significant scaler in the company's strategy which comes at a time when Indians are showing renewed interest in watching events than typical movies. According to EY-FICCI reports, the events segment is growing at a CAGR of $15 \%$ which is higher than the growth of overall media \& entertainment industry. Moreover, the margins are higher in this segment up to $40 \%$ depending on the concert. The movie-ticketing space is a volume game with thin margins at 2-5\%. This shift in focus is not attributed to competition in the space according to the founder. Rather the idea is to be one-stop destination for all ticketing needs for customers when they step out of homes.

The company also resorted to agile marketing, a tactical approach by creating lot of buzz for movies like Padmaavat and Bahubaali 2 which helped the company sell 5 million and 12 million tickets respectively.

\section{CHALLENGES AHEAD}

Albeit new competitors in the movie-ticketing space with a duopoly emerging between Paytm and Book My Show, the company has managed to retain its market share of $70 \%$. Paytm, being a digital wallet service provider has penetrated in smaller towns with its cashback and loyalty programs, a segment not so well tapped by Book My Show. Owing to deeper internet proliferation and broad band connectivity the prospects look bright in those untapped segment. The company is planning to produce and manage smaller events in Tier 2 cities and beyond where such events are unusual. Crisis management for events, rising cost, issues relating to regulation of internet handling charges of online firms by RBI in the event of a petition are other challenges faced by the company. Here are a few year-on-year growth, funding details of the company.

\begin{tabular}{|l|c|c|}
\hline \multicolumn{3}{|c|}{ Financial Statistics } \\
\hline Details & $\begin{array}{c}\text { FY 17-18 } \\
(\mathbf{C r})\end{array}$ & FY 16-17 (Cr) \\
\hline $\begin{array}{l}\text { Total } \\
\text { Revenue }\end{array}$ & 400 & 332.08 \\
\hline Growth (\%) & \multicolumn{2}{|c|}{$\mathbf{2 0 \%}$} \\
\hline $\begin{array}{l}\text { Operating } \\
\text { Revenues }\end{array}$ & 386 & 299.57 \\
\hline Growth (\%) & \multicolumn{2}{|c|}{$28 \%$} \\
\hline $\begin{array}{l}\text { Total } \\
\text { expenses }\end{array}$ & 540.97 & 460.78 \\
\hline Increase & \multicolumn{2}{|c|}{$\mathbf{1 7 . 4 0 \%}$} \\
\hline Net Loss & 140 & 128.7 \\
\hline Increase & \multicolumn{2}{|c|}{$\mathbf{1 0 \%}$} \\
\hline
\end{tabular}

\begin{tabular}{|l|l|l|}
\hline \multicolumn{3}{|c|}{ Funding Details } \\
\hline Type & Amount & Investors \\
\hline Seed & Undisclosed & Network 18 \\
\hline Series A & \$18 M & Accel \\
\hline Series B & $\$ 25 \mathrm{M}$ & Saif Partners \\
\hline & & $\begin{array}{l}\text { Accel, Saif Partners, } \\
\text { Stripes Group, } \\
\text { Network 18 }\end{array}$ \\
Series C & \$ 81.5 M & TPG Growth \\
\hline Series D & \$100 M & TPG \\
\hline
\end{tabular}

Source:startuptalky.com

\section{CONCLUSION}

The entrepreneurial orientation has stood as a testimony to the success of Book My Show. As per mint report the company sells 15 million tickets every month and has 1400 employees. It has crossed many a hurdles to command this position of market leadership. From the initial days of buying tickets and delivering them to the door steps of customers on Cash On Delivery basis, the company has gone a long way in creating an ecosystem of movieticketing. It has used technology to collaborate with multiplexes for ticket partnership. The company generated useful data using analytics that enabled the cinema halls to increase their spend per customer. It has built a solid community of E-Ticket buyers. Its expanding its footprint to internationally. All this had come through the proficient employment of technology. The company is a clear example of a technopreneurship disrupting old age businesses. Let the company hit the markets one more time with the same success for non-movie ticketing and live entertainments in the years to come as it enters the coveted cluster of Unicorns.

\section{REFERENCES}

1. C.Shekhar Upadhyay Dr.Prinyanka Rawal, Start-Ups; Lets Start Them Up - An inside view in the Indian Start Up Scenario, International Journal for Research in Applied Science \& Technology Vol 5, Issue X, Oct 2017

2. Uruba \& Singh, A study of Financing Sources for Start- 
up Companies in India International Review of Business and Finance ISSN 0976-5891 Volume 8, No.1 (2016), pp. 1-4

3. Start-Up: An Overview - ASSOCHAM Report 2016 Prepared by Grant Thornton

4. http://www.businessworld.in/article/MediaEntertainment-Industry-Reached-Rs-1-67-Trillion-In2018-FICCI-FRAMES-report-2019/12-03-2019-168117/

5. https://economictimes.indiatimes.com/markets/stocks/ear nings/bookmyshow-revenue-growth-rises-30-to-come-inat-rs-390-crore-pace-of-growth-in-lossesreduces/articleshow/66418702.cms?from $=\mathrm{mdr}$

6. https://entrackr.com/2019/07/bookmyshow-eyes-unicornstatus-with-fresh-100-mn-round-led-by-general-atlantic/

7. https://inc42.com/buzz/bookmyshows-growth-ratecontinues-to-fall-reaches-20-for-fy 18 /

8. https://www.livemint.com/companies/start-ups/quietrise-of-india's-ticketing-unicorn-1563985480102.html

9. https://startuptalky.com/startup-storybookmyshow/\#book_my_show_idea_story_history

10. https://tech.economictimes.indiatimes.com/news/internet/ inside-bookmyshows-strategy-to-go-beyond-the-boxoffice/66980267

11. https://www.thehindubusinessline.com/infotech/bookmyshow-revenue-growth-slows-to-20-at-400cr-in-fy18/article25362922.ece\#. 